\title{
AN ECONOMIC COMPARISON OF FORESTRY AND FARMING ALTERNATIVES
}

\author{
John M. KING \\ Ministry of Agriculture and Fisheries, Hastings
}

Abstract

Farm forestry must be viewed as a capital crop, the economics of which are considerably improved 'through complementary production from livestock grazing the forest floor. The grazing animals maintain a clean forest floor, do not significantly. affect the rata of tree growth, and reduce the burden of financing the necessary silvicultural operations. The greatest disadvantage is in the time delay between establishment and final income, and farmers must ensure that areas planted on farms do not unduly constrain annual income from the remaining farm area, and thereby increase the requirement for large-scale financing from external sources.

THE concePt of grazing animals on a forest floor is by no means new. Noxious animals have grazed on forest floors for as long as there have been production forests. It is only in recent times that the concept has been extended to incorporate planned grazing of domestic animals for profit in these forests.

The objective of multiple land use - forestry and farming is that of complementary production of timber and livestock products, and the Hawke's Bay region is one where this objective is being successfully realized by private and commercial foresters alike.

Of course, complementary production has a profit factor inherent in its meaning, and it is this factor that will be discussed, but with reference only to multiple land use with the Pinus radicata species.

It is important first to differentiate between "farm forests" and "forests which are farmed" as this difference has a distinct bearing on the economics of the multiple land use system. A "farm forest" is generally small in area, is often referred to as a farm woodlot which is grazed by animals, and is rarely planted as the major part of the overall farm business. Reasons for planting the woodlot at all vary widely between farmers and may include any of the following:

- Provision for estate duties. 
— Provision of capital to aid in establishing children in a farm or business in the future.

- Diversification of farm enterprises.

- A retirement fund.

- Utilization of farm labour during slack' periods.

- Other aesthetic factors.

Woodlots can be easily incorporated into the farm's grazing regime as they are usually planted in paddook sizes, fenced, usually have a water' supply, and have been planted into a good grass and clover sward. As such, they simply become a grass paddock with trees in it and, in the first 10 to 12 years, rarely result in either reduced stosk numbers or greatly increased grazing pressure on the rest of the farm.

Commercial foresters end New Zealand Forest Service on the other hand, are primarily concerned with production of forest products. Many of their forests have been established on large tracts of native country, acquired at low cost and never well suited to pastoral farming. Moist of these. areas cannot be grazed until pasture is established prior to planting of the next rotation.

Only recently have large-scale foresters recognized the potential profitability of multiple land use and are acquiring some developed farm land for forest establishment, or are developing native land areas prior to planting.

Now to the economics of establishing and maintaining such areas. Although farm woodlots do not have their economic returns to the grazing animal as clearly defined as do the larger production forest areas, the direct costs and returns are similar in many instances. An investor may have several opportunities open to him, and these can be illustrated by the flow diagram in Fig. 1.

An economic summary of each major land use alternative has been prepared as space does not allow a fully detailed schedule of comparative costs and returns. This summary is based on forest establishment on Hawke's Bay hill country capable of carrying 13 L.S.U./ha after development and which has a known forestry site index of 95." A 2-year land development phase has been included with the exception of the "forestry only" alterna-

*A eite index is the height in feet that a tree is expected to grow to on that particular site at age 20 years. This height has a direct relationship to volume of logs at time of clearfelling. 


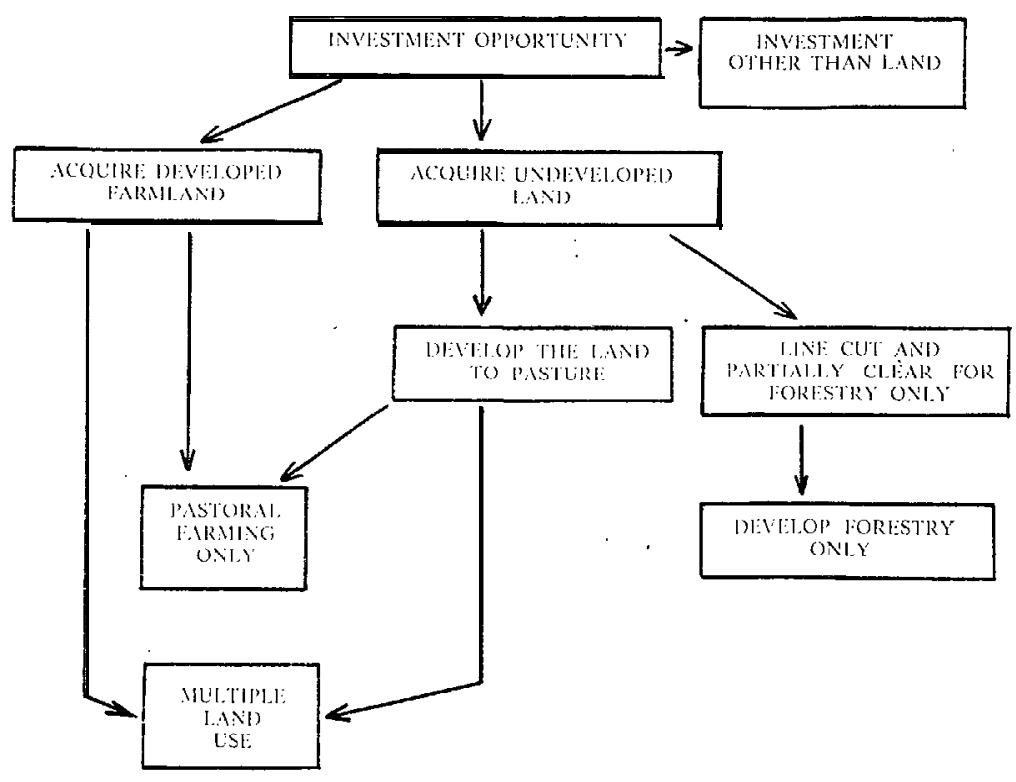

FIG, 1

tive where only line-cutting and partial clearing would be re-quired. A farmer planting a woodlot on land already developed into good pasture would not incur this cost, but if developed land was purchased for tree planting, the purchase price would certainly reflect the cost of development.

The forestry system used is that of short rotation (about 25 years) incorporating early thinning to waste, and pruning to a height of at least $6 \mathrm{~m}$. This management will ensure minimal forest floor litter and shading, and will reduce inter-tree competition. (See Appendix 1 for forestry costs.)

Stock in the forest can consist of sheep and cattle, though, in the first two years of establishment, care must be taken to avoid significant tree damage and mortality.

Estimation of stock numbers an area of forest can carry as tree size increases. is a critical factor when comparing alternatives, as is the intensity of use of the grass on the forest floor. Farmers with small woodlots tend to use their forest floors much more intensively than would a commercial company with a very large area of forest floor suitable for grazing. Generally it can be said that intensity of use will decrease with increasing area of forest, and that quality of stock production will also decrease as the 
owners tend to stock with greater proportions of dry stock which require less attention.

The economic summary includes a conservative, level of stocking in the forest, this being $35 \%$ of that for the same land under pastoral use only over the 25 -year period. It is likely that a farmer would make more intensive use of his woodlot than the $35 \%$ assumed in this analysis (see Appendix 2) .

In calculating returns, a gross margin figure of $\$ 6.50$ per L.S.U. has been used as a long-term estimate excluding inflation, and a conservative $\log$ price of $\$ 10$ net $/ \mathrm{m}^{3}$. The $\log$ price is a very sensitive factor, particularly as the market is 25 years away trom planting. The price ohanges in the past eight years above have highlighted this factor. However, a conservative estimate must be used, this value being about $28 \mathrm{c} / \mathrm{ft}^{3}$ net of all felling costs. Trees are not a perishable commodity, and can remain standing after year 25 if a depressed market for logs is operating.

The volume of marketable logs coming from an area of land can be quite accurately estimated. A yield of $450 \mathrm{~m}^{3} / \mathrm{ha}$ was used in the analysis made.

So now to the actual figures which are presented in summary form. Looking first at the gross value of a single rotation, the wide variation in gross income before tax can be seen:

Forest only: $\$ 3960 /$ ha.

Stock plus forestry: $\$ 4600 /$ ha.

Stock only: $\$ 1730 /$ ha.

In terms of gross untaxed income, the forestry with stock system is considerably more profitable than either of the other alternatives. However, these gross figures ignore taxation and also interest rates on the accumulating costs.

Taxing income from stock at $35 \mathrm{c}$ in the dollar and income from $\operatorname{logs}$ at $50 \mathrm{c}$ in the dollar, the difference between the relative profitabilities is narrowed:

Forestry only: $\$ 1980 /$ ha.

Stock plus forestry: $\$ 2360 /$ ha.

Stock only: $\$ 1130 /$ ha.

These tax rates have, been selected as marginal rates which could feasibly face a farmer, the income being generated being additional to the income from the remainder of his business and therefore taxed at his highest marginal rate. The lower rate of tax on stock certainly favours stocking policies and is one reason for the considerable narrowing of the profitability range for the three alternatives considered. The forestry costs under a multiple land use system' become a little confused when annual taxation 
is considered from a farmer's point of view. The Tax Act does not clearly state that costs incurred with production forestry can be claimed against other non-forestry income in the year in which they accrue. For this reason, the forestry costs have been carried forward and offset 'against log income at clearfelling.

The third phase of profitability comparison involves the compound interest factor. This is of greater concern to a forestry company than it is to a farmer, a factor of the areas planted and the very much larger capital requirements. A farmer with a small area of trees will usually finance operations out of income - particularly if his woodlot area is being grazed and not lost to the pastoral enterprises.

Applying a compound rate of interest of $8 \%$ on the accumulating net debt with no allowance for a forestry grant, the comparative profitabilities narrow their range still further and actually change their ranking:

Forestry only: $\$ 580 /$ ha.

Forestry plus stock: $\$ 1645 / \mathrm{ha}$.

Stock only: $\$ 1030 /$ ha.

These figures indicate the likely net income from each alternative over a 27 -year period after tax and interest charges at $8 \%$ have been met. The significant effect of the interest rate on the forestry regimes is significantly reduced if the Government's Forestry Encouragement Grant Scheme is utilized. Overall profitabilities (excluding the interest rate effect) do not change with the Grant Scheme as the grant is a tax concession in advance of income from clearfelling. However, it substantially reduces the requirement for capital throughout the rotation and significantly reduces the effect of a compounding interest rate.

At all stages throughout this analysis, the forestry plus stock alternative is the moot profitable land use system. However, these figures are the total net income over a considerable time period - 27 years. In most economic analyses involving time, a special form of investment analysis is. used to make more meaningful comparisons of profitability. This is the Internal Rate of Return concept. This technique eliminates t-be time period involved and brings investments of considerable length and different time periods back to a common basis for comparison. Although not a perfect technique, it indicates the profitability of an enterprise in terms of a compound interest rate on the captial invested.

Applying this I.R.R. technique to the three alternative land uses being compared, there is a ranking change in the order of profitability: 
Forestry only: $7.5 \%$.

Forest plus stock: $8.8 \%$.

Stock only: $15.6 \%$.

Combining all the analyses together, the profitability of the alternatives can be briefly summarized.

Excluding inflation, multiple land use is the most profitable system after tax and interest charges have been included. However, the. considerable time delay between the initial investment and the bulk of the income from logging is a major disadvantage, and a farmer must view a woodlot or small forest as a capital crop. This delay is not as serious for forestry companies. as they usually have forests of different ages, and a more regular income from logs over a given time period. Income from stock running in the forest covers little more than the forestry costs but, as such, plays a very important role by reducing the demand for external finance.

Under a land use of forestry only, the returns (excluding an interest rate) are still very attractive, but there is a major demand for money from other sources to finance the silvicultural operations.

Pastoral land use is the least profitable in total terms, but provides a regular income over the time period. If the net returns from the stock could be invested annually, the overall profitability of the pastoral landuse would be considerably improved. The I.R.R. technique assumes that this would occur automatically. Other factors not included in this analysis involve inflation, insurances, access tracking, and general forest administration.

Inflation of both costs and returns is always a factor of paramount importance when analysing the profitability of a long-term venture. Recent inflation has been very high, and many farmers who have woodlots at the pruning and thinning stages are experiencing financial difficulties in meeting the costs, out of income - a factor also associated with the decline in prices for livestock products. The size and scale of farm woodlots mast be tailored to this problem, and, if significant areas of the farm are to be planted, establishment must be staggered over a period to reduce the burden of costs and demand for labour in any one year.

Access tracking, fire insurance and administration are of small importance to a farmer, but are significant costs on the larger commercial forests planted on the harder country. 
Farming a forest or woodlot area will usually improve the profitability of a forestry <enterprise and will reduce the need for external finance. Farm woodlots are an excellent means of capital provision in the future, but care must be taken to ensure that they do not place undue strain on the rest of the farming business.

\section{APPENDIX 1}

Basic Forestry Costs Assumed in Calculations Made

Nofe: These are current costs for silvicultural operations obtained from New Zealand Forest Service in September 1975.

\begin{tabular}{lcc}
\hline Forestry 0 peration & $\begin{array}{c}\text { Established } \\
\text { Pasture } \\
(\$ / h a)\end{array}$ & $\begin{array}{c}\text { Established into } \\
\text { Partially Cleared } \\
\text { Bush and Scrub } \\
(\$ / h a)\end{array}$ \\
\hline Land development & 250 & 85 \\
Band spraying before planting & 55 & - \\
Trees (delivered) @ \$20/1000 & 30 & 40 \\
Planting labour & 50 & 65 \\
Pruning to 2.4 m & 76 & 90 (year 4/5) \\
First thinning to 600 stems/ha & 50 & 60 (year 4/5) \\
Pruning to 4.3 m & 65 & 75 (year 6/7) \\
Second thinning to 300 stems/ha & 45 & 45 year 6/7) \\
Pruning to 6 m & 62 & 65 (year 8) \\
Final thinning to 200 stems/ha & 20 & 20 (year 8) \\
\hline
\end{tabular}

Fertilizer (superphosphate) at $250 \mathrm{~kg} / \mathrm{ha}$ applied in years $2,4,6$ and 8 on forest areas planted into pasture. Stock costs and salvage values were included where appropriate at $\$ 10 /$ head.

\section{APPENDIX 2}

Stock Grazing Potential on Forest Floor

The potential stock grazing on the forest floor as used in this paper is summarized below. The grazing potential in small, farmer-owned woodlots would be greater than this, and as such the overall estimate used in the calculations made is conservative.

\begin{tabular}{lcc}
\hline Year & $\begin{array}{c}\text { Grazing } \\
(\%)\end{array}$ & $\begin{array}{c}\text { Available } \\
\text { without Trees } \\
(\text { L.S.U./ha })\end{array}$ \\
\hline 1 (planting) & 25 & 3.25 \\
$2-4$ & 80 & 10.4 \\
$5-7$ & 70 & 9.1 \\
$8-10$ & 55 & 7.15 \\
$11-12$ & 45 & 5.85 \\
$13-15$ & 30 & 3.9 \\
$16-20$ & 10 & 1.3 \\
$21-25$ & 0 & \\
Average & 35 & \\
\hline
\end{tabular}

